\title{
The circadian gene Arntl2 on distal mouse chromosome 6 controls thymocyte apoptosis
}

\section{Basile Lebailly, Francina Langa, Christian Boitard, Philip Avner \& Ute Christine Rogner}

Mammalian Genome

ISSN 0938-8990

Mamm Genome

DOI 10.1007/s00335-016-9665-4

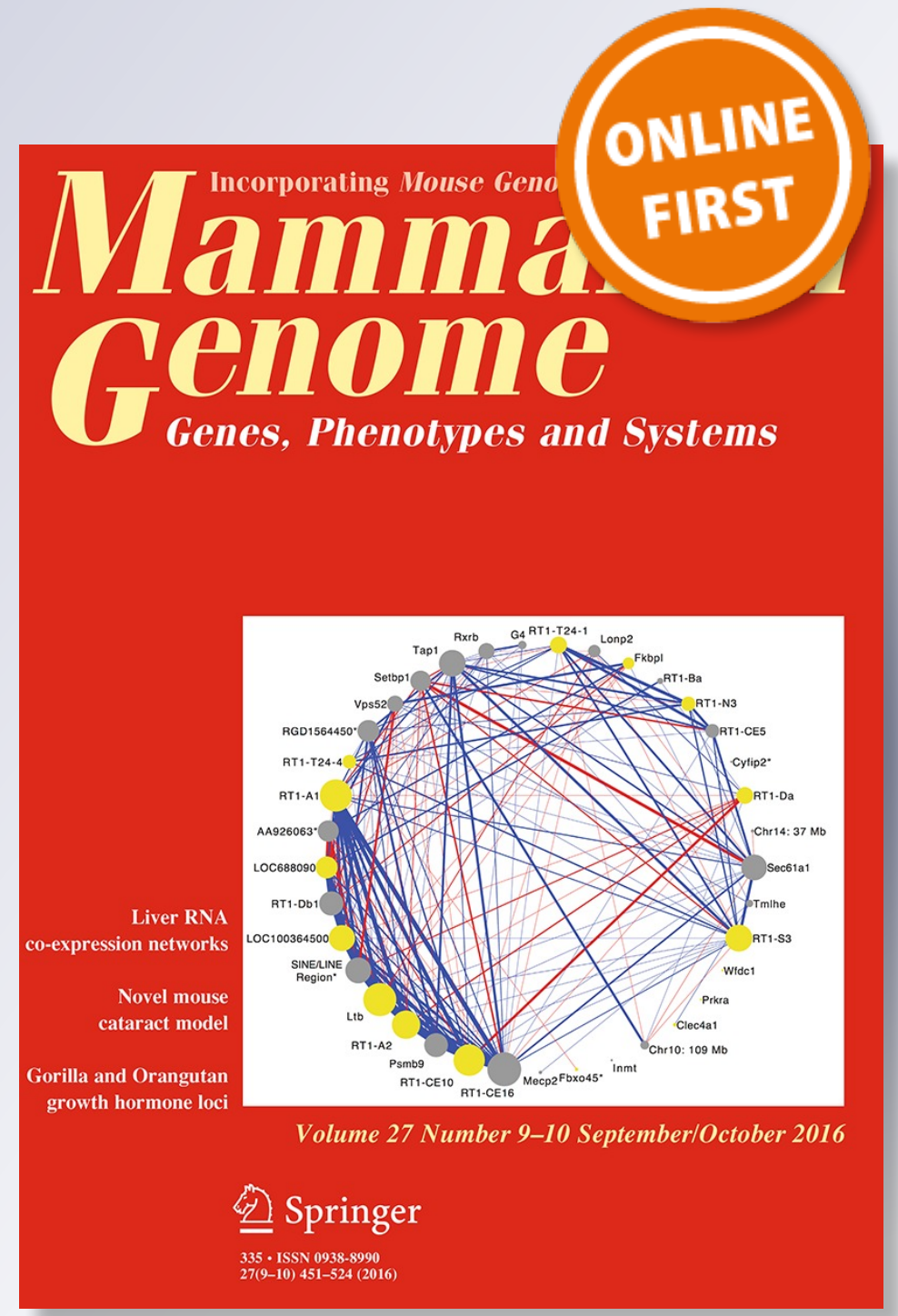

脰 Springer 
Your article is protected by copyright and all rights are held exclusively by Springer Science +Business Media New York. This e-offprint is for personal use only and shall not be selfarchived in electronic repositories. If you wish to self-archive your article, please use the accepted manuscript version for posting on your own website. You may further deposit the accepted manuscript version in any repository, provided it is only made publicly available 12 months after official publication or later and provided acknowledgement is given to the original source of publication and a link is inserted to the published article on Springer's website. The link must be accompanied by the following text: "The final publication is available at link.springer.com". 


\title{
The circadian gene Arntl2 on distal mouse chromosome 6 controls thymocyte apoptosis
}

\author{
Basile Lebailly $^{1,2} \cdot$ Francina Langa $^{3}$ - Christian Boitard ${ }^{4}$ Philip Avner ${ }^{1}$. \\ Ute Christine Rogner ${ }^{1,4}$
}

Received: 25 May 2016/ Accepted: 11 September 2016

(C) Springer Science+Business Media New York 2016

\begin{abstract}
Nonobese diabetic (NOD) mice are a model for type 1 diabetes that displays defects in central immune tolerance, including impairment of thymocyte apoptosis and proliferation. Thymocyte apoptosis is decreased in $\mathrm{NOD} / \mathrm{Lt}$ mice compared to nondiabetic $\mathrm{C} 3 \mathrm{H} / \mathrm{HeJ}$ and C57BL/6 mice. Analysis of a set of NOD.C3H and NOD.B6 congenic mouse strains for distal chromosome 6 localizes the phenotype to the $700 \mathrm{~kb}$ Idd6.3 interval. Idd6.3 contains the type 1 diabetes candidate gene aryl hydrocarbon receptor nuclear translocator-like 2 (Arntl2), encoding a circadian rhythm-related transcription factor. Newly generated $A r n t l 2^{-1-}$ mouse strains reveal that inactivation of the B6 allele of Arntl2 is sufficient to both decrease thymocyte apoptosis and proliferation. When expressed from $\mathrm{C} 3 \mathrm{H}$ or $\mathrm{B} 6$ alleles, ARNTL2 inhibits the transcription of interleukin 21 (Il21), a major player in the
\end{abstract}

Electronic supplementary material The online version of this article (doi:10.1007/s00335-016-9665-4) contains supplementary material, which is available to authorized users.

Ute Christine Rogner

ute.rogner@inserm.fr

1 Mouse Molecular Genetics Laboratory, CNRS URA 2578, Institut Pasteur, 25 rue du Docteur Roux, 75015 Paris, France

2 University Pierre and Marie Curie, Cellule Pasteur UPMC, 25 rue du Docteur Roux, 75015 Paris, France

3 Mouse Genetics Engineering Center, CNRS URA 2578, Institut Pasteur, 28 rue du Docteur Roux, 75015 Paris, France

4 Inserm U1016 - CNRS UMR8104, Groupe Hospitalier Cochin, Université Paris Descartes, 123 boulevard Port-Royal, 75014 Paris, France regulation of immune responses. IL-21 injection abolishes the B6 allele-mediated decrease of apoptosis and proliferation. Interestingly, IL-21 also leads to an increase in thymic proinflammatory Th17 helper cells. Our results identify Arntl2 as a gene controlling thymocyte apoptosis and proliferation along with Th17 development through the IL-21 pathway.

\section{Introduction}

The Idd6 locus on distal chromosome 6 is a type 1 diabetes susceptibility locus of the nonobese diabetic (NOD) mouse (Smink et al. 2005) that protects against spontaneous diabetes when replaced by alleles from C57BL/6 (B6) or C3H/ HeJ (C3H) mice (Bergman et al. 2003; Carnaud et al. 2001; Rogner et al. 2001). B6 alleles at Idd6 have also been shown to increase thymocyte apoptosis and proliferation (Bergman et al. 2003, 2001; Penha-Goncalves et al. 1995), mechanisms that have been suggested to increase the negative selection of thymocytes against self-antigens.

Genetic dissection using NOD.C3H congenic strains revealed that the Idd6.3 subinterval is responsible for the control of diabetes in splenocyte transfer assays (Hung et al. 2006). Compared to controls, splenocytes from NOD.C3H congenic mice with $\mathrm{C} 3 \mathrm{H}$ alleles at Idd6.3 transfer diabetes less efficiently, and these congenic mice exhibit lower numbers of interleukin-21 (IL-21)-producing $\mathrm{CD}^{+} \mathrm{T}$ cells in the spleen and thymus (Lebailly et al. 2014). The lower numbers of $\mathrm{CD} 4^{+} \mathrm{IL}-21^{+} \mathrm{T}$ cells correlate strongly with decreased numbers of Th17 and Th2 effector cells. Gene expression studies suggested that the aryl hydrocarbon receptor nuclear translocator-like 2 (Arntl2) gene located in Idd6.3 directly controls $I l 21$ 
expression. The direct targeting of $I l 21$ by ARNTL2 has been shown by chromatin immunoprecipitation (ChIP) experiments in NOD.C3H congenic mice. These findings led to the hypothesis that the diabetogenic activity of Idd6.3 splenocytes is controlled by ARNTL2 via the IL-21 pathway. This hypothesis has been reinforced by the fact that ARNTL2 overexpression in $\mathrm{CD}^{+}{ }^{+} \mathrm{T}$ cells decreases their diabetogenic activity and decreases IL-21 expression (He et al. 2010b; Lebailly et al. 2014).

IL-21 is a type I cytokine controlling immune responses through interaction with the common $\gamma$ chain $(\gamma \mathrm{c}) \mathrm{IL}-21$ receptor (IL-21R). IL-21 is mostly expressed by Th17 and $\mathrm{Th} 2$ subsets of $\mathrm{CD} 4^{+} \mathrm{T}$ cells and acts on its target genes via activation of the Jak/Stat, MAPK and PI3K pathways (Spolski et al. 2008; Spolski and Leonard 2014; Zeng et al. 2007). IL-21 target cells include T cells, B cells (Ozaki et al. 2004) and natural killer (NK) cells (Frederiksen et al. 2008). High levels of IL-21 boost immune responses and can induce autoimmune reactions (McGuire et al. 2011). In particular, IL-21 promotes T cell survival and thus contributes to $\mathrm{T}$ cell homeostasis and expansion (Ostiguy et al. 2007). Moreover, IL-21 not only acts as an activator of effector T cells (Monteleone et al. 2008), but it also antagonizes the suppressive activity of regulatory $\mathrm{T}$ cells (Peluso et al. 2007), an effect that is also genetically controlled by Idd6 (Rogner et al. 2006). Finally, IL-21 controls recovery of thymocytes from apoptosis and is essential for the differentiation of Th17 cells in the thymus via the activation of the RAR-related orphan receptor gamma (ROR $\gamma$ ) pathway (Rafei et al. 2013b; Sofi et al. 2010). Il21 is a candidate gene for T1D and is located in the murine locus Idd3 (McGuire et al. 2009; Spolski et al. 2008; Sutherland et al. 2009). NOD alleles show increased expression of $I l 21$ compared to B6 alleles (McGuire et al. 2009).

$\mathrm{C} 3 \mathrm{H}$ and $\mathrm{B} 6$ alleles of Arntl2 give rise to proteins that can bind to the RNA polymerase II binding site of the $I l 21$ promoter, leading to reduced Il21 transcription. Conversely, NOD Arntl2 alleles do not translate into proteins that bind to $I l 21$, thus leading to high $I l 21$ expression. In the present work, we show that mutation of the B6 allele of Arntl2 leads to increased numbers of $\mathrm{CD} 4^{+} \mathrm{IL}-21^{+} \mathrm{T}$ cells in spleen and thymus. High levels of Arntl2 expressed from $\mathrm{C} 3 \mathrm{H}$ and $\mathrm{B} 6$ alleles in $\mathrm{CD} 4^{+} \mathrm{CD}^{+}{ }^{+} \mathrm{T}$ cells precede low numbers of IL-21-producing $\mathrm{CD} 4^{+} \mathrm{T}$ cells. The mutation of Arntl2 in C57BL/6 and in Idd6 NOD.B6 congenic mice also decreases the number of apoptotic thymocytes. Exogenous IL-21 decreases apoptosis and increases the number of IL-21-producing $\mathrm{CD} 4^{+} \mathrm{T}$ cells in the nonmutant N.B6 congenic strain, thus mimicking both $A r n t l 2^{-1-}$ phenotypes. Our results suggest that Arntl2 is involved in controlling thymocyte apoptosis and proliferation, which appear to be directly linked to the IL-21 pathway.

\section{Materials and methods}

\section{Construction of mouse strains}

NOD.C3H congenic mice for Idd6 have been described previously (Hung et al. 2006; Rogner et al. 2001) (Online Resource 1). The Arntl2 mutant strain carries the allele Arntl $^{\mathrm{tmla(KOMP)Wtsi}}$ and has been imported from the UCDavis KOMP Repository (Davis, CA). The C57BL/6derived Idd6 interval (including B6 alleles at D6Mit14 to D6Mit304) has been transferred to the NOD background by crossing females to the NOD/Lt strain, followed by 7 backcrosses and subsequent intercrossing to obtain homozygous mice. In parallel, Idd6 NOD.B6 congenic mice (including B6 alleles at D6Mit14 to D6Mit304) were generated as controls (Online Resource 1). Closer examination of the SNPs in the region indicated that the B6derived interval of both strains includes the marker rs39946360 (144.6 Mb) and excludes the marker rs37447988 (144.4 Mb).

To select for NOD alleles at Idds outside of Idd6, the following markers were used:

\begin{tabular}{ll}
\hline Idd & Markers \\
\hline Idd5 & D1Mit18 and D1Mit180 \\
Idd13 & D2Mit395, D2Mit17 and D2Mit525 \\
Idd3 & D3Nds6 and D3Mit95 \\
Idd10/17/18 & D3Mit95, D3Mit100, and D3Mit345 \\
Idd9 & D4Mit203 \\
Idd11/25 & D4Mit203 and D4Mit59 \\
Idd15 & D5Mit346 and D5Mit48 \\
Idd20/19/ & D6Mit69, D6Mit55 \\
Idd7 & D7Mit20 and D7Mit328 \\
Idd2 & D9Mit25 \\
Unnamed & D10Mit87 \\
Idd4 & D11Mit339 and D11Mit298 \\
Idd14 & D13Mit16 and D13Mit61 \\
Idd8 & D14Mit110 \\
Idd12 & D14Mit222 \\
Idd1/16 & D17Mit34 \\
Idd21 & D18Mit171, D18Mit202, D18Mit208, D18Mit4 \\
\hline
\end{tabular}

Mutations in the coding region of exon 4 of the NODderived Arntl2 gene were created using the TALEN approach. The constructs pTAL.CMV-T7.012672 and pTAL.CMV-T7.013000, designed to target the sequences TCCAGGTCAGAATTCAT and GGAAAGTCTTCCCCAGA, respectively, were provided and validated by Single Strand Annealing assay (Cellectis, Paris, France). In vitro-transcribed RNA (6-10 ng; Ambion mMESSAGE mMACHINE Kit, Life Technologies, St. Aubin, France) 
was pronuclear injected into one-cell stage NOD embryos at the Institut Pasteur Transgenesis Facility (Paris, France). Out of 39 offsprings, two mutants were identified (5\%). NT28 was a female carrying a 25-bp deletion that removes the amino acids (AA) 13-22 and introduces a 2-bp frameshift. NT58 was a male carrying a deletion of AA22 and a conversion of the aspartic acid at AA23 to alanine, but leaving the rest of the gene unaffected. These heterozygous offsprings were crossed to NOD mice and rendered homozygous by intercrossing at the F2 generation.

The absence of protein in the knockout strains was validated by Western blotting using anti-ARNTL2 antibodies (ab86530; Abcam, Paris, France). Diabetes incidence monitoring and diabetes transfer assays were performed as previously described (Lebailly et al. 2014; Rogner et al. 2006). All mice were kept at the Institut Pasteur mouse facility. All animal studies have been approved by the relevant institutional review boards (Comité d'Ethique en Expérimentation Animale CEEA 59, IDF, Paris and C2EA 89, Paris) under protocol numbers 2009-0015 and 2013-125, and the French ministry of higher education and research (Ministère de l'enseignement supérieur et de la recherche) under the reference number 02120.02 .

\section{Flow cytometry analysis}

Expression of $\mathrm{T}$ cell-specific proteins was analysed on a Cyan flow cytometer (Beckman Coulter, Villepinte, France) or a Fortessa flow cytometer (BD Biosciences, Le Pont de Claix, France) after surface and/or intracellular staining using anti-mouse antibodies specific for CD4 (Alexa Fluor 488 or Pacific Blue, BD Biosciences), TCR (PerCP-Cy5.5, BD Biosciences), CD8 (PE-Cy7, BD Biosciences or AF700, eBioscience, Paris, France), IL-17 (Alexa Fluor 488, eBioscience), IL-21 (PE, eBioscience), IFN- $\gamma$ (Alexa Fluor 700, BD Biosciences), IL-4 (APC, BD Biosciences) and FOXP3 (PerCP-Cy5.5, eBioscience). Briefly, cells were stimulated for $4 \mathrm{~h}$ with phorbol myristate acetate (PMA, $25 \mathrm{ng} / \mathrm{ml}$, Sigma, St. Louis, MO) and ionomycin $(10 \mu \mathrm{g} / \mathrm{ml}$, Sigma) in the presence of Brefeldin A (10 $\mu \mathrm{g} / \mathrm{ml}$, BD Biosciences). The cells were then washed in phosphate-buffered saline (PBS) with $0.5 \%$ bovine serum albumin, incubated with eBioscience fixation/permeabilization buffers according to the manufacturer's protocol, and stained with fluorescent antibodies. Analysis of $\mathrm{CD}^{+}$thymocyte maturation was performed using antimouse antibodies specific for CD4 (eVolve 605, eBioscience), TCR (APC-eFluor 780, eBioscience), CD8 (eVolve 655, eBioscience), CD69 (PE-Cyanine 7, eBioscience), CD5 (APC, eBioscience) and Qa2 (FITC, eBioscience).
Proportions of apoptotic cells in thymic cell populations of 2- to 3-week-old female mice were analysed by flow cytometry using the FITC Annexin V apoptosis detection kit 1 (BD Biosciences). The proportions of apoptotic cells positive for Annexin V, negative for propidium iodide, were calculated amongst the different $\mathrm{T}$ cell populations selected on their CD4 and CD8 surface expressions. Phases of the cell cycle were identified using propidium iodide (BD Biosciences) and Ki-67 (eFluor 450, eBioscience) stainings.

All analyses were performed with the FlowJo software package, and statistical analyses employed the MannWhitney test. Examples of the gating strategies are shown in the Online Resource 2.

\section{IL-21 injection}

Mice were injected daily intraperitoneally with $12.5 \mu \mathrm{g}$ per $\mathrm{kg}$ weight of rIL-21 (594-ML-010, R\&D Systems, Minneapolis, USA) diluted in $100 \mu \mathrm{l}$ of PBS or $100 \mu \mathrm{l}$ of PBS alone for controls, for 3 days before the testing.

\section{RNA extraction, reverse transcription (RT) and quantitative PCR}

Thymic $\mathrm{CD} 4^{+}, \mathrm{CD}^{+}$and $\mathrm{CD} 4^{+} \mathrm{CD} 8^{+} \mathrm{T}$ cells $\left(2 \times 10^{5}\right.$ each) were isolated by labelling with anti-mouse CD4 (Pacific Blue, BD Biosciences) and CD8 antibodies (PE$\mathrm{Cy} 7, \mathrm{BD}$ Biosciences), followed by cell sorting using a BD FACSAria III. RNA extraction and RT-PCR were done as previously described (Lebailly et al. 2014). All quantifications were performed by real-time PCR in the presence of SYBR Green (Roche, Boulogne-Billancourt, France) on three replicates. The amplification quantification in arbitrary units was performed by the DeltaCt method using three replicates and Arpo expression as an endogenous control to normalize mRNA levels. Data were analysed as mean $\pm \mathrm{SD}$ for single experiments and as mean $\pm \mathrm{SE}$ for multiple experiments. When appropriate, the differences between two groups were analysed using the MannWhitney method.

Chromatin immunoprecipitation (ChIP) was done using the primer pairs Am1-Am4 as previously described (Lebailly et al. 2014). Quantifications were performed by realtime PCR in the presence of SYBR Green (Roche) on three replicates using $50 \mathrm{ng}$ DNA. The results were calculated and normalized as $\left(C_{\mathrm{t}}\right.$ of $\mathrm{IP} / C_{\mathrm{t}}$ of input $) /\left(C_{\mathrm{t}}\right.$ of control $-\mathrm{IP} / C_{\mathrm{t}}$ of input) and compared to binding at the transcription start of Arpo (AU = 1) (Lebailly et al. 2014). Data were analysed as mean \pm SD for single experiments and as mean \pm SE for multiple experiments. 


\section{Results}

Identification of the Idd6.3 gene Arntl2 as candidate for controlling thymocyte apoptosis and proliferation

Previous studies on NOD.B6 congenic strains had shown that the locus Idd6 is involved in the control of thymocyte apoptosis and proliferation (Bergman et al. 2003, 2001; Penha-Goncalves et al. 1995). Our results confirm such findings for C57BL/6 mice and show that also $\mathrm{C} 3 \mathrm{H} / \mathrm{HeJ}$ mice exhibit higher numbers of apoptotic $\mathrm{T}$ cells in the thymus compared to NOD/Lt mice. The effect on apoptosis in these strains was found for double-positive (DP) CD4 ${ }^{+} \mathrm{CD}^{+}{ }^{+}$T cells $(P=0.001$ for $\mathrm{C} 3 \mathrm{H}$ and $P=0.008$ for B6) and single-positive (SP) $\mathrm{CD} 4^{+} \mathrm{T}$ cells $(P=0.001$ for $\mathrm{C} 3 \mathrm{H}$ and $P=0.008$ for $\mathrm{B} 6$ ), and in $\mathrm{C} 3 \mathrm{H}$ mice for SP $\mathrm{CD}^{+} \mathrm{T}$ cells $(P=0.001)$ (Fig. 1a-c). Further analysis of our NOD.C3H congenic mice showed that $\mathrm{C} 3 \mathrm{H}$ alleles at Idd6 in strain 6.VIII gave results comparable to $\mathrm{C} 3 \mathrm{H}$ mice $(P>0.2$ against $\mathrm{C} 3 \mathrm{H}, P=0.001$ against NOD for all cell types). Amongst the subcongenic strains, the 6.VIIIa strain $(\mathrm{C} 3 \mathrm{H}$ alleles at Idd6.1) showed apoptosis comparable to NOD ( $P>0.18$ for all cell types), whilst strains 6. VIIIb (Idd6.2) and 6.VIIIc (Idd6.3) showed results similar to NOD $(P<0.02$ for all cell types). These results point to a candidate interval of 623-kb controlling thymocyte apoptosis (D6Mit373 to D6Mit15, Mouse Ensembl Release 84), overlapping the previously described $3-\mathrm{Mb}$ interval controlling resistance to apoptosis distal to D6Mit200 on mouse chromosome 6 (Bergman et al. 2003).

We therefore addressed the question if the Idd6.3 candidate gene Arntl2 is involved in thymocyte apoptosis. Like the Idd6 NOD.C3H strain 6.VIII, the N.B6 strain shows increased apoptosis in all cell types when compared to NOD $\left(P=0.001\right.$ for DP and SP CD4 ${ }^{+}$T cells, $P=0.011$ for $\mathrm{CD}^{+}$cells). Mutation of Arntl2 in NOD.B6 congenic mice (strain N.B6A2 ${ }^{-}$) decreased apoptosis compared to the N.B6 control congenic strain and gave results similar to NOD mice $(P>0.142$ for all cell types). In contrast to what was observed in the NOD.C3H congenic strains 6.VIIIa and 6.VIIIc $(P=0.008$ for all cell types), the effect between the two N.B6 congenics was found in $\mathrm{CD} 4^{+} \mathrm{CD} 8^{+} \mathrm{T}$ cells $(P=0.008)$ and in $\mathrm{SP} \mathrm{CD} 4^{+} \mathrm{T}$ $(P=0.037)$ cells but not significantly in $\mathrm{SP} \mathrm{CD}^{+} \mathrm{T}$ $(P=0.296)$ cells. Similar observations were made for C57BL/6 Arntl2 knockout mice $(P=0.012$ for DP and SP $\mathrm{CD}^{+}, P=0.196$ for $\mathrm{SP} \mathrm{CD} 8^{+}, \mathrm{B} 6 \mathrm{~A} 2^{-}$compared to B6), suggesting that the apoptosis phenotype is linked to Arntl2 and independent of the genetic background. The frameshift mutation of Arntl2 in NOD mice did not have a strong influence on apoptosis $(P=0.037$ for DP, $P=0.316$ for
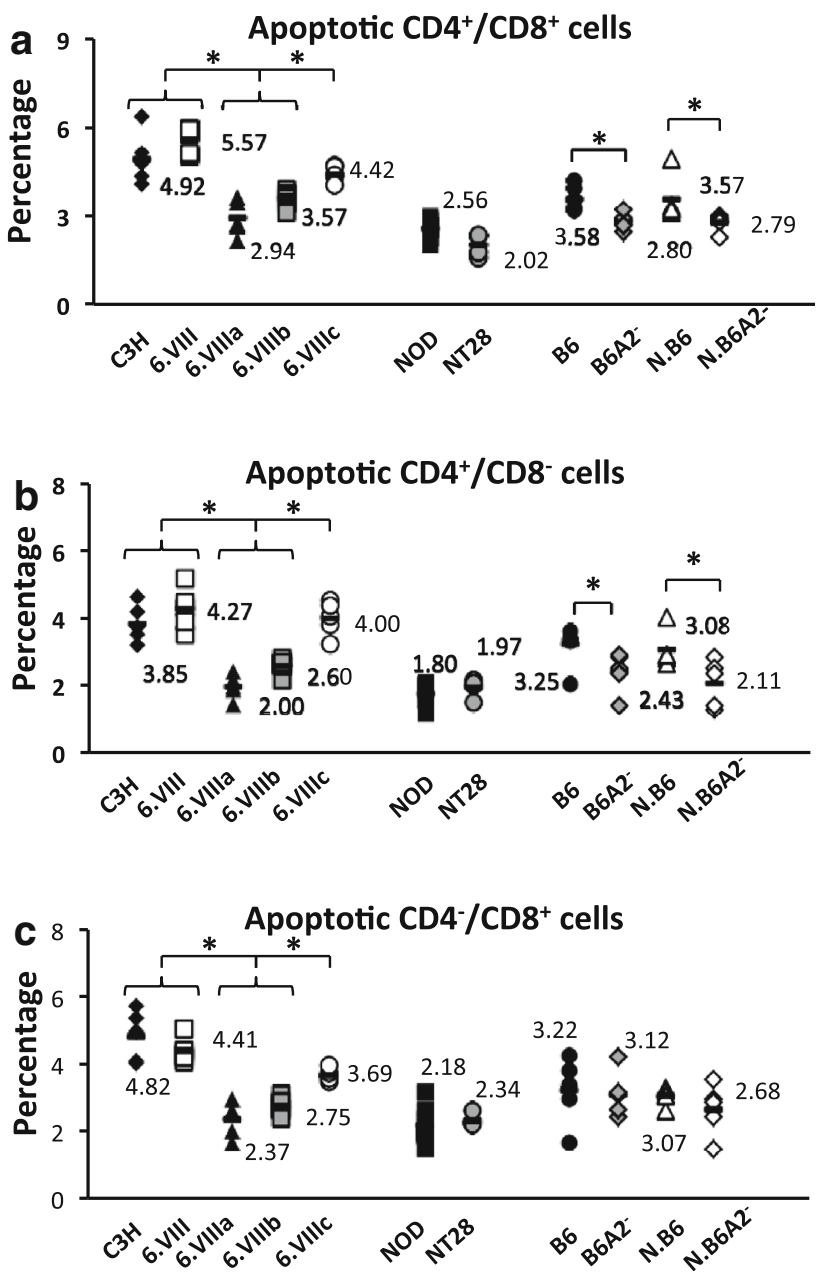

Fig. 1 Proportions of apoptotic cells, positive for Annexin V, negative for propidium iodide, amongst a $\mathrm{CD} 4^{+} / \mathrm{CD} 8^{+}, \mathbf{b} \mathrm{CD} 4^{+} /$ $\mathrm{CD} 8^{-}$and $\mathbf{c ~} \mathrm{CD}^{-} / \mathrm{CD}^{+} \mathrm{T}$ cells in the thymus of the different strains of mice (see Online Resource 1) in 3-week-old females. $n=5,6$.VIII and 6.VIIIb: $n=4, * P<0.05$; NOD alleles at Idd6.3 (strains 6.VIIIa or 6.VIIIb vs $\mathrm{C} 3 \mathrm{H}, 6$. VIII or 6.VIIIc) and Arntl2 mutation (B6A2 ${ }^{-}$vs B6, N.B6A2 ${ }^{-}$vs N.B6) lead to decrease of apoptosis

SP T cells, NT28 compared to NOD). These results indicate that Arntl2 is involved in the control of thymocyte apoptosis and suggest that $\mathrm{C} 3 \mathrm{H}$ alleles and $\mathrm{B} 6$ alleles at Idd6.3/Arntl2 increase thymocyte apoptosis compared to NOD alleles.

Higher proportions of apoptotic cells could be indicative of a general loss of thymocytes. However, the total numbers of thymocytes were found to be similar. For example, we found $0.82 \times 10^{7} \pm 2.4 \times 10^{5}$ cells for 6.VIIIa, $0.78 \times 10^{7} \pm 12 \times 10^{5}$ for 6 .VIIIc, $0.67 \times 10^{7} \pm 15 \times$ $10^{5}$ for N.B6A2 ${ }^{-}$and $0.73 \times 10^{7} \pm 2.8 \times 10^{5}$ for N.B6 ( $n=5$ using 3 -week-old females). The proportions of DN, DP and SP cells were also found to be similar. Closer examination of the cell cycle using the N.B6 congenic strains revealed that mutation of Arntl2 led to significant 
changes of the proportions of cells in G0/G1 phase (Fig. 8). Interestingly, the Arntl2 knockout strain N.B6A2 ${ }^{-}$exhibited higher numbers of cells in G0 phase and lower numbers of cells in G1 phase, indicating that the mutation may lead to cell cycle arrest. However, analysis of developmental $\mathrm{T}$ cell (DP1-DP3) and $\mathrm{CD} 4^{+} \mathrm{T}$ cell maturation stages (SP1-SP4) revealed no significant changes (Table 1).

\section{Arntl2 in Idd6.3 is sufficient to control $\mathrm{CD4}^{+} \mathrm{IL}^{-21}{ }^{+}$ $\mathrm{T}$ cell numbers}

We previously described that the presence of $\mathrm{C} 3 \mathrm{H}$ alleles at the Idd6.3 locus increases the number of $\mathrm{CD} 4{ }^{+} \mathrm{IL}-21^{+} \mathrm{T}$ cells in the spleen and thymus of NOD.C3H congenic mice (Lebailly et al. 2014). Further analysis revealed that C3H/ $\mathrm{HeJ}$ mice and C57BL/6 mice produce significantly lower percentages of $\mathrm{CD} 4{ }^{+} \mathrm{IL}-21^{+} \mathrm{T}$ cells compared to NOD/Lt mice in the spleen and thymus (Figs. 2a, 3a). These differences in $\mathrm{CD} 4{ }^{+} \mathrm{IL}-21^{+} \mathrm{T}$ cells are genetically linked to the Idd6 locus, as shown by the NOD.C3H 6.VIII strain and by the newly generated Idd6 NOD.B6 congenic strain N.B6. Further analysis of Idd6 NOD.C3H congenic mice showed that the phenotype is exclusively linked to Idd6.3 (strain 6.VIIIc), whilst the loci Idd6.1 (strain 6.VIIIa) and Idd6.2 (strain 6.VIIIb) are not implicated (Figs. 2a, 3a).

To address the question whether Arntl2 alone is sufficient to control the number of $\mathrm{CD} 4^{+} \mathrm{IL}-21^{+} \mathrm{T}$ cells, we tested our newly created knockout strains. Using N.B6 congenic strains, we found that Arntl2 mutation leads to an increase in $\mathrm{CD} 4{ }^{+} \mathrm{IL}-21^{+} \mathrm{T}$ cells. Again, differences were found in both spleen and thymus. Arntl2 mutation in
C57BL/6 gave similar results, and the frameshift Arntl2 mutation in the NT28 strain had no effect on the number of $\mathrm{CD} 4{ }^{+} \mathrm{IL}-21^{+} \mathrm{T}$ cells compared to NOD mice (Figs. 2a, 3a). These results demonstrate that Arntl2 is sufficient for controlling the production of $\mathrm{CD} 4^{+} \mathrm{IL}-21^{+} \mathrm{T}$ cells. The phenotype is independent of the genetic background. These differences in IL-21-producing cells were found in thymic $\mathrm{CD} 4^{+} \mathrm{T}$ cells; however, we detected no differences in thymic $\mathrm{CD}^{+} \mathrm{CD}^{+}$and $\mathrm{CD}^{+} \mathrm{T}$ cell populations, for which we observed less than $0.1 \% \mathrm{IL}-21^{+} \mathrm{T}$ cells for all strains.

We further observed that the differences in IL-21-producing $\mathrm{CD} 4^{+} \mathrm{T}$ cells correlated well with differences in $\mathrm{CD} 4^{+} \mathrm{IL}-17^{+} \mathrm{T}$ cells (Figs. $2 \mathrm{~b}, 3 \mathrm{~b}$ ), consistent with the notion that amongst $\mathrm{CD} 4^{+} \mathrm{T}$ cells, the Th17 subset is the main source of IL-21. We also examined if the previously described difference in Th2 cell numbers were present in the knockout strains (Lebailly et al. 2014). The number of $\mathrm{CD} 4^{+} \mathrm{IL}^{+}{ }^{+} \mathrm{T}$ cells was significantly increased in the thymus of the N.B6A2 ${ }^{-}$strain compared to the N.B6 strain. Interestingly, the findings were not confirmed for the spleen, and the mutations on the B6 and NOD genetic background had no effect. This could indicate that Arntl2 is not tightly controlling Th2 numbers. The Arntl 2 mutation did neither influence Th1 $\left(\mathrm{CD}^{+}{ }^{+} \mathrm{IFN}-\gamma^{+}\right)$cell numbers (Figs. 2d, 3d) nor the numbers of regulatory $\mathrm{CD}^{+-}$ FOXP $^{+} \mathrm{T}$ cells (see below).

We also observed that all strains with higher percentages of IL-21-producing $\mathrm{CD} 4^{+} \mathrm{T}$ cells exhibited less apoptotic cells in the thymus, indicating that these two phenotypes are genetically linked. This suggested that high levels of IL-21 may reduce thymocyte apoptosis and that Arntl2 may control this pathway.

Table 1 Numbers and percentages of immune cells per one million thymocytes of 3-week old female mice

\begin{tabular}{|c|c|c|}
\hline Cell type (marker) & Strain N.B6 $(n=5)$ & Strain N.B6A2 ${ }^{-}(n=5)$ \\
\hline $\mathrm{CD}^{-} \mathrm{CD}^{-}$ & $59437(5.99 \%) \pm 9963(0.99 \%)$ & $63,437(6.36 \%) \pm 9245(0.92 \%)$ \\
\hline $\mathrm{CD}^{+} \mathrm{CD}^{+}$(total) & $777,366(77.79 \%) \pm 55,274(5.53 \%)$ & $753,772(75 \%) \pm 62,392(6.31 \%)$ \\
\hline $\begin{array}{l}\mathrm{CD} 4^{+} \mathrm{CD}^{+} \mathrm{DP} 1\left(\mathrm{TCR}^{\text {low }}\right. \\
\left.\mathrm{CD} 5^{\text {low }}\right)\end{array}$ & $\begin{array}{l}587,377\left(75.56 \% \text { of } \mathrm{CD}^{+} \mathrm{CD}^{+}\right) \pm 27,363 \\
\quad(3.52 \%)\end{array}$ & $\begin{array}{l}597,891\left(79.32 \% \text { of } \mathrm{CD}^{+} \mathrm{CD}^{+}\right) \pm 972,365 \\
\quad(1.29 \%)\end{array}$ \\
\hline $\mathrm{CD}^{+} \mathrm{CD}^{+} \mathrm{DP} 2\left(\mathrm{TCR}^{\mathrm{int}} \mathrm{CD} 5^{\mathrm{hi}}\right)$ & $\begin{array}{l}83,255\left(10.71 \% \text { of } \mathrm{CD}^{+} \mathrm{CD}^{+}\right) \pm 22,388 \\
\quad(2.88 \%)\end{array}$ & $62,939\left(8.35 \%\right.$ of $\left.\mathrm{CD}^{+} \mathrm{CD}^{+}\right) \pm 9459(1.255 \%)$ \\
\hline $\mathrm{CD} 4^{+} \mathrm{CD} 8^{+} \mathrm{DP} 3\left(\mathrm{TCR}^{\mathrm{hi}} \mathrm{CD} 5^{\text {int }}\right)$ & $\begin{array}{l}42,599\left(5.48 \% \text { of the } \mathrm{CD}^{+} \mathrm{CD}^{+}\right) \pm 6607 \\
(0.85 \%)\end{array}$ & $\begin{array}{l}33,768\left(4.48 \% \text { of the } \mathrm{CD} 4^{+} \mathrm{CD}^{+}\right) \pm 3693 \\
(0.49 \%)\end{array}$ \\
\hline $\mathrm{CD}^{+} \mathrm{CD}^{-}$(total) & $127,637(12.76 \%) \pm 28,155(2.81 \%)$ & $150,960(15.1 \%) \pm 38,248(3.82 \%)$ \\
\hline $\begin{array}{l}\mathrm{CD} 4^{+} \mathrm{CD}^{-} \mathrm{SP} 1 / 2\left(\mathrm{CD} 9^{+}\right. \\
\left.\mathrm{Qa}^{-}\right)\end{array}$ & $\begin{array}{l}96,340\left(75.48 \% \text { of } \mathrm{CD}^{+} \mathrm{CD}^{-}\right) \pm 19,490 \\
\quad(15.27 \%)\end{array}$ & $\begin{array}{l}112,208\left(74.32 \% \text { of } \mathrm{CD}^{+}{ }^{+} \mathrm{CD} 8^{-}\right) \pm 15,234 \\
(10.09 \%)\end{array}$ \\
\hline $\mathrm{CD}^{+} \mathrm{CD}^{-} \mathrm{SP} 3\left(\mathrm{CD}^{-} 9^{-} \mathrm{Qa}^{-}\right)$ & $14,691\left(11.51 \%\right.$ of $\left.\mathrm{CD}^{+} \mathrm{CD}^{-}\right) \pm 2042(1.6 \%)$ & $19,398\left(12.85 \%\right.$ of $\left.\mathrm{CD}^{+} \mathrm{CD}^{-}\right) \pm 3698(2.45 \%)$ \\
\hline $\begin{array}{l}\mathrm{CD} 4+\mathrm{CD}^{-} \mathrm{SP} 4\left(\mathrm{CD}^{-} 9^{-}\right. \\
\left.\mathrm{Qa}^{+}\right)\end{array}$ & $14,001\left(10.97 \%\right.$ of $\left.\mathrm{CD}^{+}{ }^{+} \mathrm{CD}^{-}\right) \pm 7530(5.89 \%)$ & $\begin{array}{l}21,949\left(14.54 \% \text { of the } \mathrm{CD} 4^{+} \mathrm{CD}^{-}\right) \pm 3170 \\
(2.1 \%)\end{array}$ \\
\hline $\mathrm{CD}^{-}{ }^{-} \mathrm{CD} 8^{+}$ & $35,861(3.59 \%) \pm 3999(0.4 \%)$ & $33,130(3.31 \%) \pm 4064(0.41 \%)$ \\
\hline
\end{tabular}



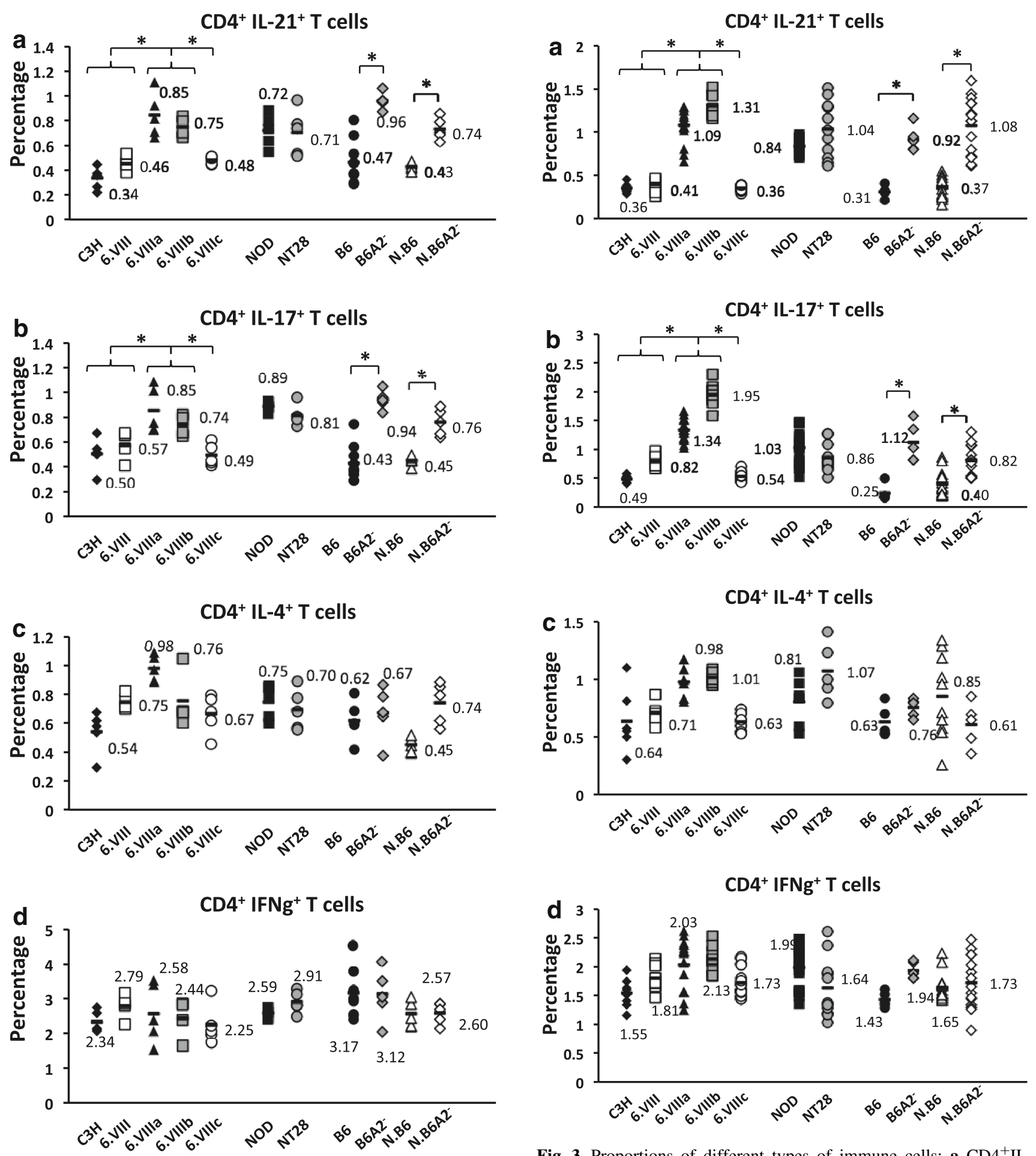

Fig. 2 Proportions of different types of immune cells: a $\mathrm{CD} 4^{+} \mathrm{IL}-$ $21^{+}$, b CD $4^{+} \mathrm{IL}-17^{+}$, $\mathbf{c ~ C D} 4^{+} \mathrm{IL}-4^{+}$and $\mathbf{d ~ C D} 4^{+} \mathrm{IFN} \gamma{ }^{+}$in the thymus of 3-week-old females. $n=5$ : 6.VIII and 6.VIIIb, $n=4$ : B6. $n=10$, $* P<0.05$

Fig. 3 Proportions of different types of immune cells: a $\mathrm{CD} 4^{+} \mathrm{IL}-$ $21^{+}$, b CD $4^{+} \mathrm{IL}-17^{+}, \mathbf{c ~ C D} 4^{+} \mathrm{IL}-4^{+}$and $\mathbf{d ~ C D} 4^{+} \mathrm{IFN}-\gamma^{+}$in the spleen of 5- to 6-week-old females of the different mouse strains. $\mathrm{C} 3 \mathrm{H}$, 6.VIII, 6.VIIIb: $n=9$; 6.VIIIa, 6.VIIIc, NOD: $n=19$; NT28: $n=11, \mathrm{~B} 6, \mathrm{~B} 6 \mathrm{~A} 2^{-}: n=5 ; \mathrm{N} . \mathrm{B} 6, \mathrm{~N} . \mathrm{B} 6 \mathrm{~A} 2^{-}: n=15, * P<0.05$ 


\section{ARNTL2 alleles exhibit variations in their coding sequences}

Since we have previously shown that $\mathrm{C} 3 \mathrm{H}$ alleles of Arntl2 give rise to proteins that can bind to the promoter of the Il21 gene, we validated by ChIP that the B6 alleles of Arntl2 also give rise to proteins that can bind to the RNA polymerase II binding site $922 \mathrm{bp}$ upstream of the first exon (Fig. 4a) in this promoter. Mutation of the B6 allele abolished the binding, and no binding was detected for NOD Arntl2 alleles compared to C3H (Lebailly et al. 2014) and B6 (Fig. 4b) alleles. As previously reported, we did not detect any binding of the ARNTL2 partners ARNTL1 or CLOCK at this site of interaction (not shown).

The canonical sequence of the ARNTL2 protein comprises 579 amino acids (AA), including four conserved domains (bHLH AA48-101, PAS1 AA119-190, PAS2 AA296-366 and PAC AA371-414). To explore if variations in the ARNTL2 protein sequence may explain the absence of binding of the NOD protein to the Il21 promoter, we examined the previously published sequences (Hung et al. 2006; Stewart et al. 2003) together with more recent polymorphisms included in the Ensembl database and annotated by the Sanger Mouse Genomes Project. From a total of 62 variants affecting the coding region, we eliminated the synonymous variants and those that were not polymorphic between NOD/ $\mathrm{Lt}, \mathrm{C} 3 \mathrm{H} / \mathrm{HeJ}$ and $\mathrm{C} 57 \mathrm{BL} / 6$ strains from our further analysis. From the remaining 15 variants, 5 were different between NOD and $\mathrm{C} 3 \mathrm{H}, 13$ between NOD and $\mathrm{B} 6$, and 12 between $\mathrm{C} 3 \mathrm{H}$ and $\mathrm{B} 6$. Interestingly, the NOD allele differs in only 3 coding variants from both $\mathrm{C} 3 \mathrm{H}$ and B6 alleles at AA71, 450 and 481 (Table 2). The variant at AA71 is located in the bHLH DNA-binding domain and appears to be the only variant with a low SIFT value (Ng and Henikoff 2001; Sim et al. 2012), predicting that the leucine to methionine replacement in the NOD allele might be deleterious for protein function. Such prediction does not exclude that the other variations in the NOD sequence have functional effects, although they all locate outside of the conserved domains. Recent publications have shown that the C-terminal domains of the protein can have important roles in the activation or repression of transcriptional activities (Xu et al. 2015).

We next examined Arntl2 expression levels at different thymocyte differentiation stages. In the NOD.C3H congenics 6.VIIIa and 6.VIIIc, the highest Arntl2 expression was found in double-positive (DP) $\mathrm{CD} 4^{+} \mathrm{CD} 8^{+} \mathrm{T}$ cells. This result was confirmed in the N.B6A2 ${ }^{-}$strain compared to the N.B6 strain (Fig. 5d). This indicates that transcriptional changes of Arntl2 precede the measurable
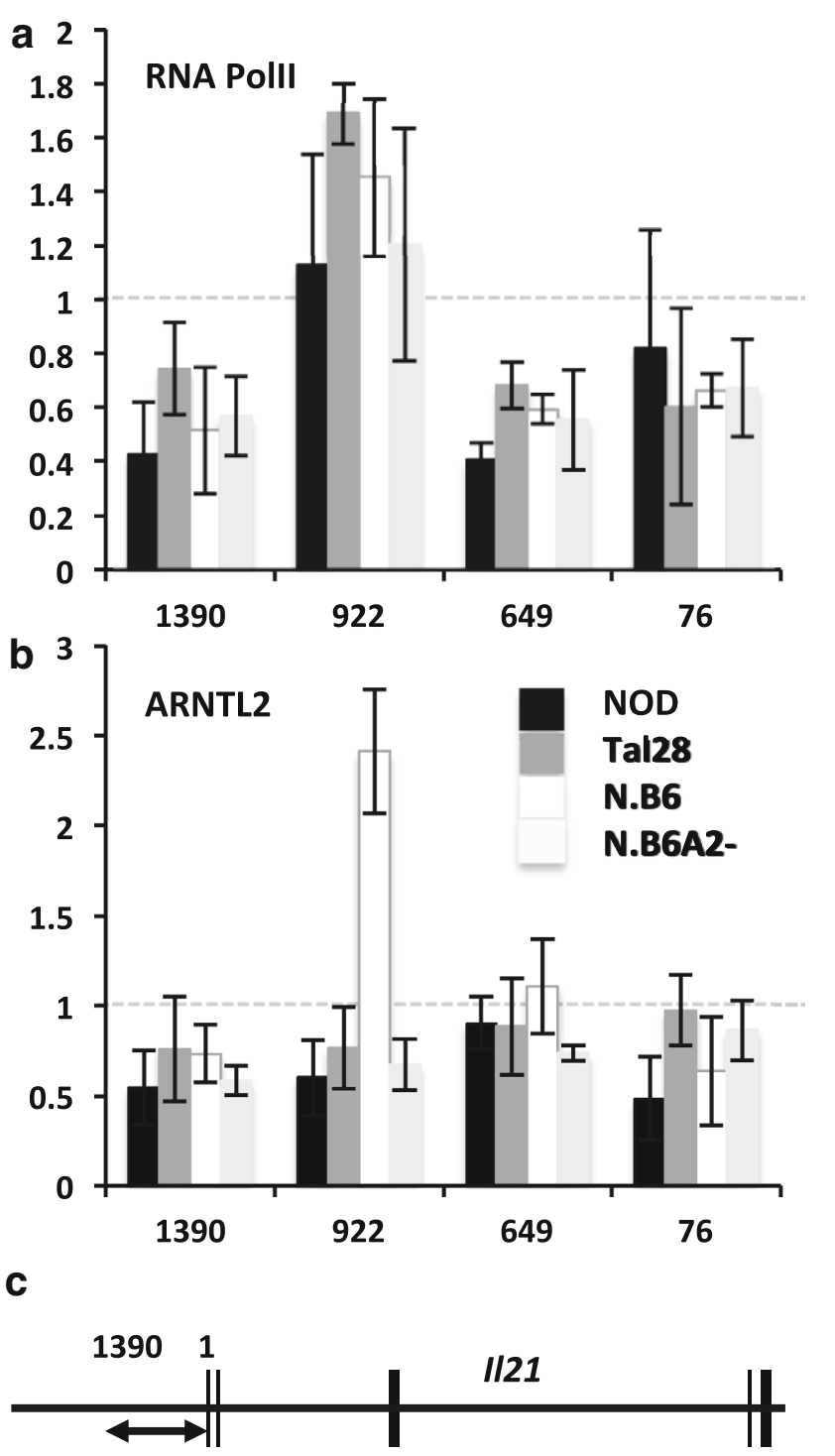

Fig. 4 ChIP analysis of a RNA POL II and b ARNTL2 on the Il21 promoter using different mouse strains. Two independent tests $( \pm)$ SE using splenocytes from three 5-week-old female mice each are shown. The results represent arbitrary units and were calculated and normalized as $\left(C_{\mathrm{t}}\right.$ of IP/ $C_{\mathrm{t}}$ of input $) /\left(C_{\mathrm{t}}\right.$ of control $-\mathrm{IP} / C_{\mathrm{t}}$ of input $)$ and compared to binding at the transcription start of Arpo (dashed grey line) (Lebailly et al. 2014). Positions are indicated in bps upstream of the coding start of the Il21 gene at bp 37232618 on mouse chromosome 3 (Ensembl GRCm38.p4). The structure of $I l 21$ gene $(10 \mathrm{~kb})$ is shown in panel (c), exons are marked as black boxes, the arrow marks the promoter region under investigation

differences of IL-21 expression in $\mathrm{CD} 4^{+} \mathrm{T}$ cells. In these experiments, increased levels of Arntl2 correlated with lower expression of $\mathrm{Il21}$ in $\mathrm{CD} 4^{+} \mathrm{CD} 8^{+} \mathrm{T}$ cells (Fig. 5b, e). No changes in $I l 17$ transcripts were detected (Fig. 5c), confirming that the increase of Th17 cells in the mutant does not correlate with increased $1 l 17$ transcript levels (Lebailly et al. 2014). 
B. Lebailly et al.: The circadian gene Arntl2 on distal mouse chromosome 6 controls

Table 2 Codon variants of the ARNTL2 protein

\begin{tabular}{|c|c|c|c|c|c|c|c|c|c|}
\hline \multirow{2}{*}{$\begin{array}{l}\text { AA } \\
\text { residue }\end{array}$} & \multirow{2}{*}{$\begin{array}{l}\text { Variant } \\
\text { identifier }\end{array}$} & \multirow[t]{2}{*}{ Consequence } & \multirow[t]{2}{*}{ Alleles } & \multirow{2}{*}{$\begin{array}{l}\text { Resulting } \\
\text { codons }\end{array}$} & \multirow{2}{*}{$\begin{array}{l}\text { Resulting } \\
\text { AA }\end{array}$} & \multicolumn{3}{|c|}{ Alleles in } & \multirow{2}{*}{$\begin{array}{l}\text { SIFT } \\
\text { prediction }\end{array}$} \\
\hline & & & & & & NOD & $\mathrm{C} 3 \mathrm{H}$ & B6 & \\
\hline 71 & rs36388854 & Missense & $\mathrm{C} / \mathrm{A}$ & CTG, ATG & $\mathrm{L}, \mathrm{M}$ & AA & $\mathrm{CC}$ & $\mathrm{CC}$ & Deleterious (0) \\
\hline 164 & rs48247052 & Missense & $\mathrm{A} / \mathrm{G}$ & ATA, ATG & $\mathrm{I}, \mathrm{M}$ & GG & GG & AA & $\begin{array}{c}\text { Tolerated } \\
(0.13)\end{array}$ \\
\hline 207 & rs29924777 & Missense & $\mathrm{T} / \mathrm{C}$ & TAC, CAC & $\mathrm{Y}, \mathrm{H}$ & $\mathrm{CC}$ & $\mathrm{CC}$ & $\mathrm{TT}$ & Tolerated $(0.9)$ \\
\hline 213 & rs30073811 & Missense & $\mathrm{A} / \mathrm{G}$ & ATG, GTG & $\mathrm{M}, \mathrm{V}$ & GG & GG & $\mathrm{AA}$ & $\begin{array}{c}\text { Tolerated } \\
(0.31)\end{array}$ \\
\hline 423 & rs 48852525 & Missense & $\mathrm{T} / \mathrm{G}$ & CAT, CAG & $\mathrm{H}, \mathrm{Q}$ & GG & GG & $\mathrm{TT}$ & $\begin{array}{c}\text { Tolerated } \\
(0.57)\end{array}$ \\
\hline 425 & rs225458185 & Missense & $\mathrm{G} / \mathrm{A} / \mathrm{T}$ & GGC, AGC & $\mathrm{G}, \mathrm{S}$ & GG & AA & GG & Tolerated (1) \\
\hline 426 & rs49229642 & Missense & $\mathrm{G} / \mathrm{A} / \mathrm{T}$ & GGC, AGC & $\mathrm{G}, \mathrm{S}$ & GG & $\mathrm{AA}$ & GG & Tolerated (1) \\
\hline 450 & rs247782630 & Missense & G/A & GTC, ATC & $\mathrm{V}, \mathrm{I}$ & AA & GG & GG & $\begin{array}{l}\text { Tolerated } \\
\quad(0.41)\end{array}$ \\
\hline 479 & rs212813005 & Missense & G/A & AGC, AAC & $\mathrm{S}, \mathrm{N}$ & AA & AA & GG & $\begin{array}{c}\text { Tolerated } \\
(0.09)\end{array}$ \\
\hline 481 & rs259733556 & Inframe deletion & AGA/- & TCAGAA, TCA & SE, $S$ & $(-/-)$ & $\begin{array}{c}(+/ \\
+)\end{array}$ & $\begin{array}{c}(+/ \\
+)\end{array}$ & No data \\
\hline 494 & rs49176210 & Missense & $\mathrm{A} / \mathrm{G}$ & AAT, AGT & $\mathrm{N}, \mathrm{S}$ & GG & GG & AA & $\begin{array}{c}\text { Tolerated } \\
(0.76)\end{array}$ \\
\hline 494 & rs586986482 & Missense & AT/GC & AAT, AGC & $\mathrm{N}, \mathrm{S}$ & GG & GG & AA & $\begin{array}{c}\text { Tolerated } \\
(0.76)\end{array}$ \\
\hline 504 & rs49078756 & Missense & $\mathrm{C} / \mathrm{T}$ & CCT, CTT & $\mathrm{P}, \mathrm{L}$ & TT & TT & $\mathrm{CC}$ & $\begin{array}{c}\text { Tolerated } \\
(0.88)\end{array}$ \\
\hline 511 & rs50619963 & Missense & G/A & GAA, AAA & E, $K$ & AA & AA & GG & $\begin{array}{c}\text { Tolerated } \\
(0.35)\end{array}$ \\
\hline 535 & rs50518043 & $\begin{array}{l}\text { Missense splice } \\
\text { variant }\end{array}$ & $\mathrm{G} / \mathrm{A}$ & GGT, AGT & $\mathrm{G}, \mathrm{S}$ & GG & GG & AA & $\begin{array}{c}\text { Tolerated } \\
(0.52)\end{array}$ \\
\hline
\end{tabular}

Sequence variants leading to amino acid (AA) changes in ARNTL2 in NOD/Lt, C3H/HeJ and C57BL/6 mice. AA 71 locates to the bHLH domain, AA 164 and 207 both to the PAS1 domain

\section{IL-21 administration rescues thymocyte apoptosis and increases Th17 numbers}

We next tested if exogenous IL-21 could decrease thymocyte apoptosis (Rafei et al. 2013a). Preliminary tests showed that recombinant IL-21 (rIL-21) doses of $12.5 \mu \mathrm{g} /$ $\mathrm{kg}$ were most effective, whilst higher doses of $25 \mu \mathrm{g} / \mathrm{kg}$ and $50 \mu \mathrm{g} / \mathrm{kg}$ were less effective. Injection of $12.5 \mu \mathrm{g} / \mathrm{kg}$ rIL-21 during 3 days clearly decreased the percentage of apoptotic $\mathrm{CD}^{+}{ }^{+} \mathrm{CD}^{+}$and $\mathrm{CD} 4{ }^{+} \mathrm{CD} 8^{-} \mathrm{T}$ cells in the N.B6 congenic strain. The rIL-21 administration reduced apoptosis to similar percentages observed in the N.B6A2 ${ }^{-}$strain (Fig. 6). IL-21 injection also led to increased numbers of DP and SP cells in G0 phase (Fig. 8) in the N.B6 congenics. No effect of rIL-21 on apoptosis or proliferation was found for the N.B6A2 ${ }^{-}$knockout mice. Interestingly, also the number of IL-21- and IL-17-producing cells increased in the N.B6 congenic strain after rIL-21 injection, whilst the number of $\mathrm{CD}^{+} \mathrm{FOXP}^{+}$and $\mathrm{CD}^{+}{ }^{+} \mathrm{INF}-$
$\gamma^{+}$T cells did not change significantly (Fig. 7). Neither the number of $\mathrm{IL}-21^{+} \mathrm{T}$ cells or of $\mathrm{IL}-17^{+} \mathrm{T}$ cells changed in the knockout mice. This result indicates that the pathways are regulated by IL-21, and that the inhibitory effects of ARNTL2 can be rescued by exogenous IL-21.

\section{Discussion}

\section{Genetic control of thymocyte apoptosis in Idd6}

The NOD mouse displays defects in the selection of $\mathrm{T}$ lymphocytes in the thymus. NOD genetic variation influences, for example, the $\alpha \beta / \gamma \delta$ lineage decision promoted by early expression of transgenic $\alpha \beta$ TCRs at the DN stage (Mingueneau et al. 2012). The NOD mouse also displays defects in the mechanism(s) mediating programmed cell death in T lymphocytes (Guler et al. 2005; Leijon et al. 1994). Defects in thymic negative selection are thought to 

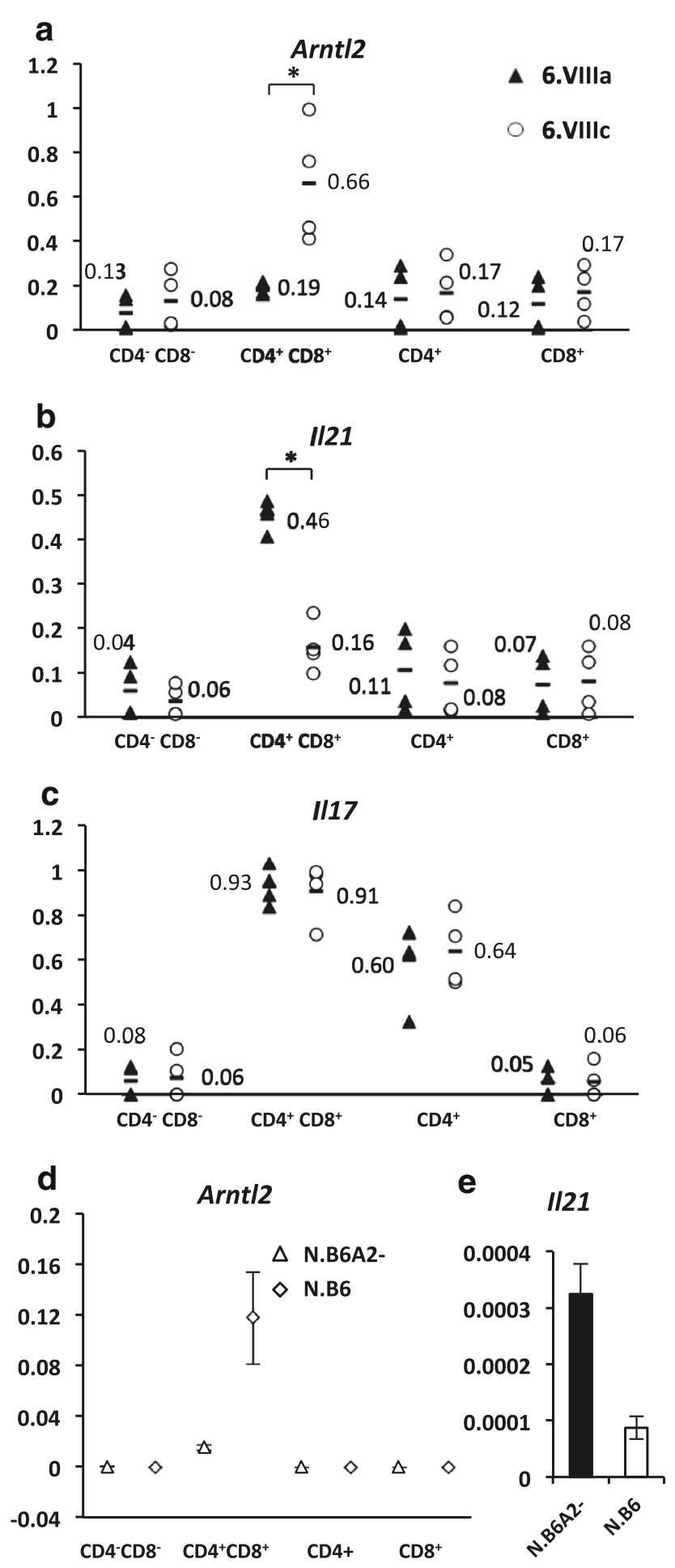

Fig. 5 Expression of a Arntl2, b $I l 21$ and $\mathbf{c} I l 17$ in the different stages of development of the lymphocytes in the thymus of the strains 6.VIIIa and 6.VIIIc. The results are shown as arbitrary units. $n=4$ using two 2-week-old female mice each. * $P<0.001$ (MannWhitney test). Expression for Arntl2 in strains N.B6 and N.B6A2 ${ }^{-}$is shown in panel (d) (2 experiments \pm SE using 2 female mice each). Corresponding expression of $\mathrm{Il} 21$ in $\mathrm{CD} 4{ }^{+} \mathrm{CD} 8{ }^{+} \mathrm{T}$ cells is shown under (e)
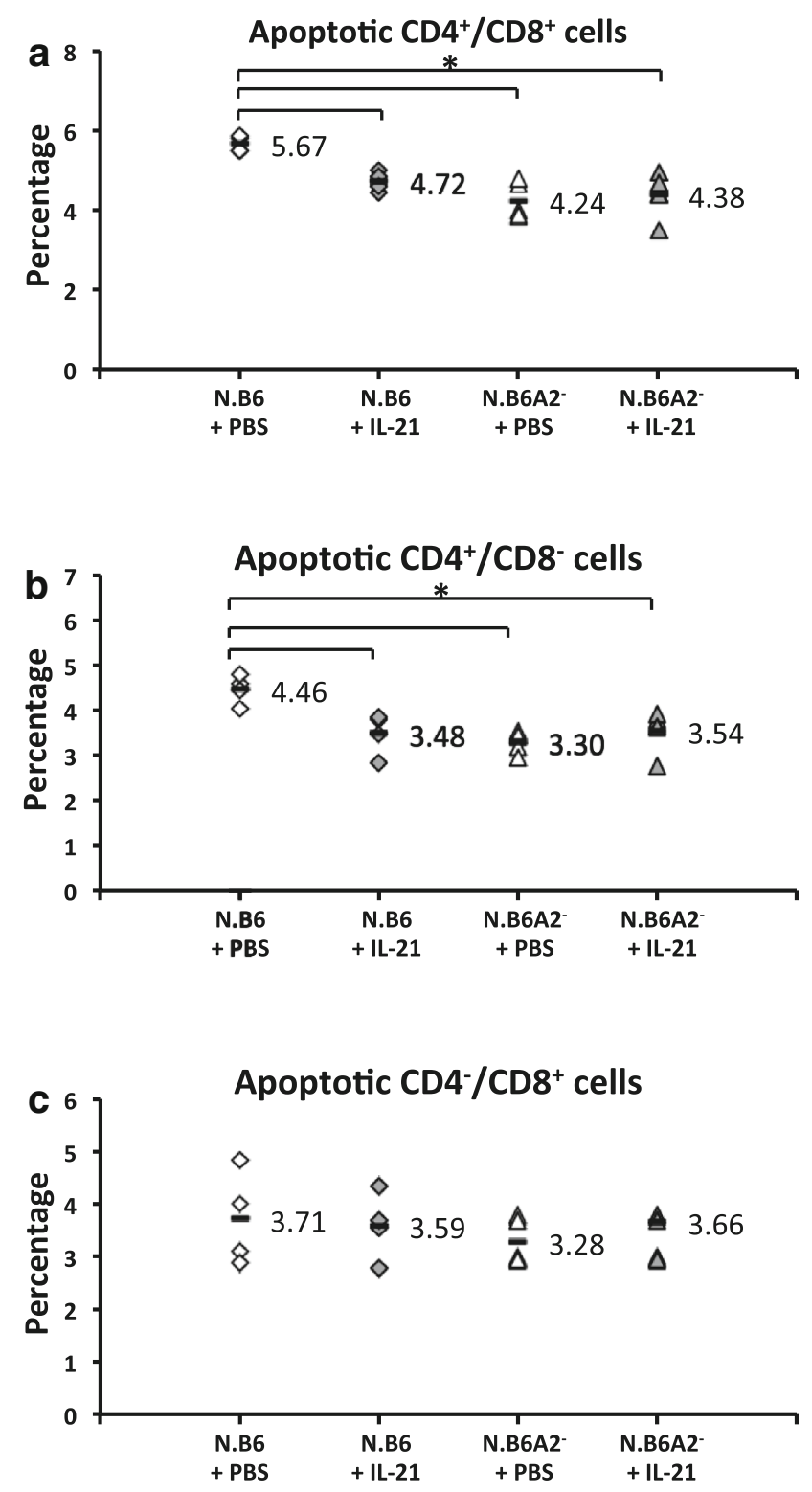

Fig. 6 Proportions of apoptotic cells amongst a $\mathrm{CD} 4^{+} / \mathrm{CD}^{+}$, b $\mathrm{CD}^{+} / \mathrm{CD}^{-}$and $\mathbf{c} \mathrm{CD} 4^{-} / \mathrm{CD} 8^{+}$cells in the thymus of 3 -weekold females N.B6 or N.B6A2 ${ }^{-}$mice after 3 daily injections with either PBS or IL-21 $(12.5 \mu \mathrm{g} / \mathrm{kg}) . n=5, * P<0.05$

result in failure to delete $\beta$-cell-reactive $\mathrm{T}$ cells, thus contributing to T1D development (Kwon et al. 2005), and autoreactive diabetogenic $\mathrm{T}$ cells are likely to result from an inappropriate selection of DP thymocytes in NOD mice.

Previous genetic analyses have mapped $\mathrm{T}$ cell proliferative effects and induced apoptosis to Idd6 and more precisely to the Idd6.1-Idd6.3 interval (Bergman et al. 2003; 2001, Duarte et al. 2007; Penha-Goncalves et al. 1995). Our present study localizes apoptosis effects in SP and DP $\mathrm{T}$ cells to $I d d 6$ and $I d d 6.3$. Both $\mathrm{B} 6$ and $\mathrm{C} 3 \mathrm{H}$ alleles at $I d d 6$ increase the number of apoptotic cells compared to NOD alleles. The Arntl2 ${ }^{-1-}$ NOD.B6 and C57BL/6 mice confirm 

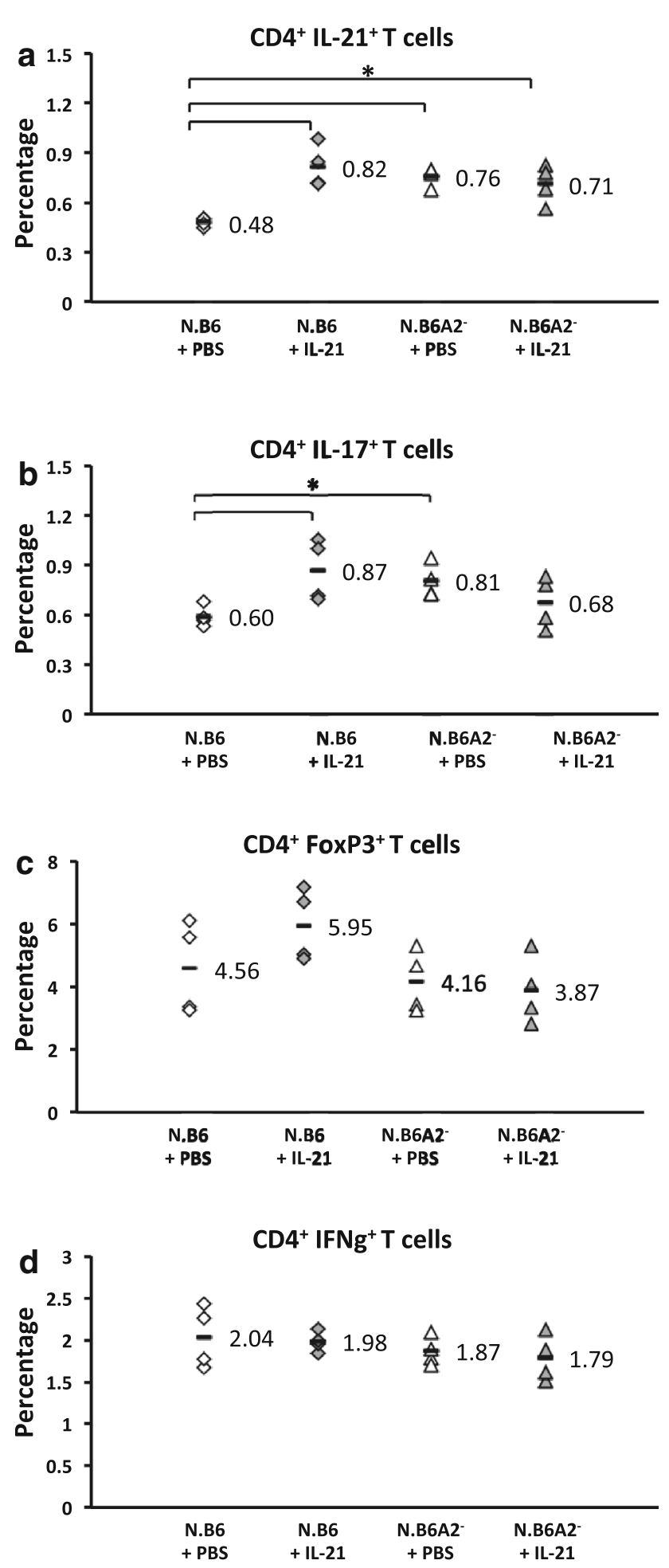

Fig. 7 Proportions of different types of immune cells: a $\mathrm{CD} 4{ }^{+} \mathrm{IL}-$ $21^{+}$, b $\mathrm{CD} 4^{+} \mathrm{IL}-17^{+}$, c $\mathrm{CD} 4^{+} \mathrm{FoxP} 3^{+}$and $\mathbf{d ~ C D} 4^{+} \mathrm{IFN}-\gamma^{+}$in the thymus of 3-week-old females N.B6 and N.B6A2 ${ }^{-}$after three daily injection with either PBS or IL-21 $(12.5 \mu \mathrm{g} / \mathrm{kg}) . n=4 .{ }^{*} P<0.05$

the result for DP $\mathrm{T}$ and $\mathrm{SP} \mathrm{CD} 4^{+} \mathrm{T}$ cells but not for $\mathrm{CD} 8^{+}$ $\mathrm{T}$ cells. The differences in affected cell populations could be due to the different alleles or due to other genes present in the Idd6.3 interval. Our results also show that thymocyte apoptosis effects in Arntl2 knockouts depend on the gene itself but not on the genetic background of the autoimmune NOD model.

Our present results indicate Arntl2-related changes in apoptosis and in cell cycle. So far, we could neither detect changes in $\mathrm{CD}^{+}{ }^{+} \mathrm{T}$ cell maturation nor in the TCRV $\beta$ repertoire (TCRVß chains $2-7,8.1,8.2,9-14,17$ ) of thymic SP $\mathrm{CD}^{+}$and $\mathrm{CD}^{+}{ }^{+} \mathrm{T}$ cells. Interestingly, also IL-21 treatment has been shown to not skew the TCRV $\beta$ repertoire during recovery from induced thymocyte apoptosis (Rafei et al. 2013a).

\section{Arntl2 and the IL-21 pathway in thymocyte development}

We previously suggested and hereby confirm that Arntl2 controls $I l 21$ expression (Lebailly et al. 2014). C3H and B6 alleles of Arnt 2 encode proteins that inhibit $I l 21$ expression; NOD alleles and mutated B6 alleles of Arntl2 increase the level of $I l 21$ and the number of IL-21-producing cells in the thymus and spleen.

Our present study shows also that differences in IL-21 expression are related to the differences in Arntl2 expression in $\mathrm{CD} 4^{+} \mathrm{CD}^{+}$thymocytes. It has been shown that IL21 inhibits thymocyte apoptosis (Rafei et al. 2013b) and increases recovery from induced apoptosis (Rafei et al. 2013a). This suggests that the observed changes in IL-21 expression may be related to the differences in apoptosis. Our IL-21 injection studies clearly support this model. IL21 induces differentiation of Th17 cells (Deenick and Tangye 2007; Sofi et al. 2010; Wei et al. 2007), and higher IL-21 levels could also be responsible for the increased numbers of Th17 cells amongst $\mathrm{CD} 4^{+} \mathrm{T}$ cells. However, and for both phenotypes, exogenous IL-21 at the applied doses seems inefficient in the Arntl2 ${ }^{-/-}$strain. One possible but not exclusive explanation to this may be that the higher endogenous levels of IL-21 have already saturated the pathways.

\section{Arntl2 as a type 1 diabetes candidate gene}

Idd6 has been identified as a NOD susceptibility locus in several independent studies. Bergmann et al. (Bergman et al. 2003) already reported protective effects for B6 alleles at $I d d 6$ in a larger $8 \mathrm{cM}$ interval excluding the NK locus (Carnaud et al. 2001), and Duarte et al. excluded the distal $3 \mathrm{cM}$ interval (D6Mit15-D6Mit304) from the candidate region (Duarte et al. 2007). Our results suggest that B6 alleles at the D6Mit14-D6Mit304 interval confer diabetes protection in the NOD mouse (Online Resource 3). Taken together, these data suggested that spontaneous diabetes incidence is decreased when B6 alleles are present 


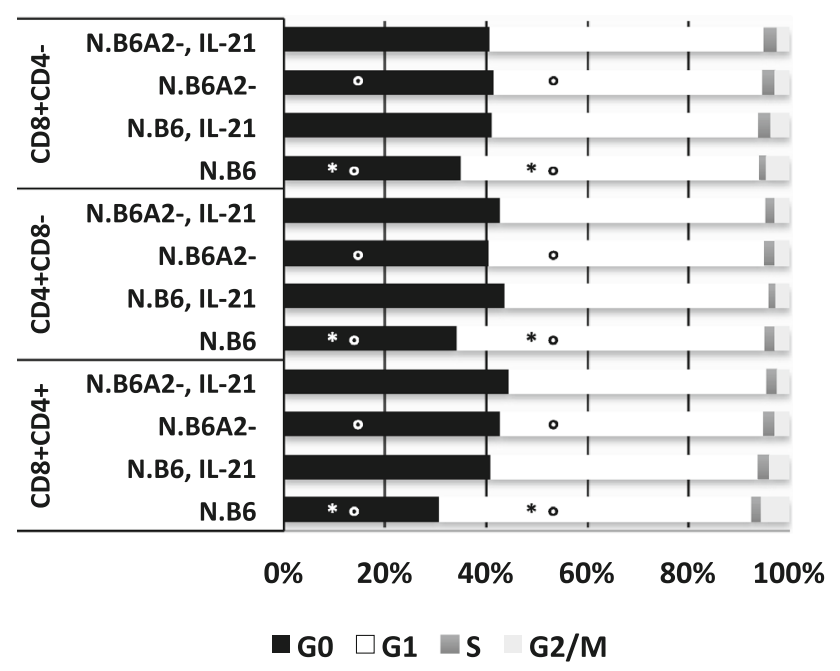

Fig. 8 Cell cycle analysis of thymocytes using propidium iodide and Ki-67 stainings. Percentages of cells in different phases of the cell cycle are shown for five 3-week-old females of strains N.B6 and N.B6A2 ${ }^{-}$, each with or without IL-21 treatment. Asterisk $P<0.05$ for comparison of injection of IL-21 injection versus PBS; Degree $P<0.05$ for comparison between the two strains. The data present one experiment out of two with similar results

at the D6Mit14-D6Mit15 interval, corresponding to the Idd6.2 locus defined by the NOD.C3H congenics (strain 6.VIIIb) (Hung et al. 2006). The results also suggest that protection in NOD.B6 congenic strains is not controlled by $I d d 6.1$ and $I d d 6.3$. When testing diabetes incidence of the newly created congenic strains, we found that mutation of Arntl2 alone is clearly not sufficient to alter the spontaneous diabetes incidence in the Idd6 NOD.B6 congenic strain (Online Resource 3). Also, the mutation of the NOD allele of Arntl2 (strain NT28) did not significantly affect diabetes incidence compared to NOD control mice generated in the same experiment. At 30 weeks of age, the incidence was $74 \% \quad(n=23$ females) for control and $57 \%(n=21$ females $)$ for female mice carrying the frameshift mutation, respectively. Taken together, the data suggest that neither Idd6.3 nor Arntl2 alone affects spontaneous diabetes incidence in the congenic strains. One reason may lie in the genetic complexity of the region. It would probably require congenic strains to carry $\mathrm{C} 3 \mathrm{H}$ or $\mathrm{B} 6$ alleles only at $I d d 6.3$ to completely clarify this issue. Another reason for the insignificant changes in the knockout may be due to the age-specific action of Arntl2-related phenotypes (Lebailly et al. 2014) that are lastly too small to have an impact on the diabetes incidence.

Interestingly and as already observed for the Idd6.3 locus in the NOD.C3H strains 6.VIIIa and 6.VIIIc, the presence of Arntl2 strongly decreases diabetes transfer using the NOD.B6 mice as splenocyte donors (Online Resource 3). These results are in line with previous

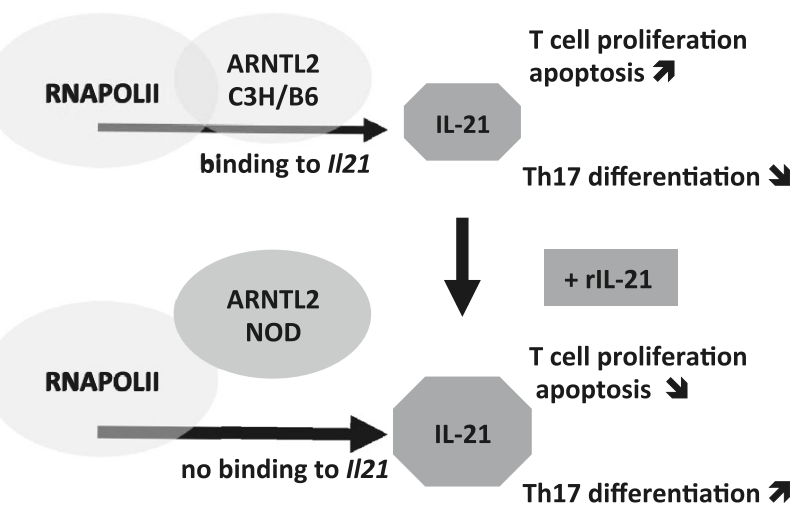

Fig. 9 Model for ARNTL2 action on IL-21 levels in the thymus. ARNTL2 proteins expressed from $\mathrm{C} 3 \mathrm{H}$ and $\mathrm{B} 6$ alleles bind to $\mathrm{Il21}$, resulting in lower numbers of IL21-expressing cells. Low levels of IL-21 lead to increase in apoptosis and $\mathrm{T}$ cell proliferation, and decrease of Th17 differentiation, resulting in higher $\mathrm{T}$ effector cell ratios. Recombinant IL-21 (rIL-21) can rescue these phenotypes

findings that increased Arntl2 expression in peripheral $\mathrm{CD}^{+}{ }^{+} \mathrm{T}$ cells induces $\mathrm{Il} 21$ expression and inhibits diabetes development (He et al. 2010a, b), but they require further examination of the cellular and molecular mechanisms involved. Interestingly, the here described altered NOD allele had no effect on diabetes transfer $(n=5$ for both groups, $80 \%$ diabetic at 12 weeks). It would however require generation of different alleles and expression levels to definitively argue that the NOD Arntl2 allele has become ineffective in the mouse, at least for its role in the immune system (Fig. 8).

\section{Conclusion}

Our work shows that the circadian rhythm-related gene Arntl2 links control of $I l 21$ expression to Th17 development and thymocyte apoptosis. In summary, low or absent expression of Arntl2 leads to increased levels of IL-21, promoting the development of Th17 cells, whilst reducing the ability of other $\mathrm{T}$ cells to proliferate, finally reducing the equilibrium between regulatory $\mathrm{T}$ cells and proinflammatory T helper cells (Fig. 9).

Acknowledgments We thank Pierre-Henri Commère, Corinne Veron, Chantal Bécourt, Gaelle Chauveau-Le Friec and Abokouo Zago for technical assistance, and Roberto Mallone for correcting the manuscript. The authors acknowledge the financial support of their work by Laboratoire d'Excellence Revive (Investissement d'Avenir; ANR-10-LABX-73), European Foundation for the Study of Diabetes (EFSD)/Juvenile Diabetes Research Foundation (JDRF)/Novo Nordisk Programme, Domaine d'intérêt majeur (DIM): CardiovasculaireObésité-Rein-Diabète (CORDDIM) and by recurrent funding from the Centre national de la recherche scientifique (CNRS), Institut national de la santé et de la recherche médicale (INSERM) and Institut Pasteur. 


\section{References}

Bergman ML, Penha-Goncalves C, Lejon K, Holmberg D (2001) Low rate of proliferation in immature thymocytes of the non-obese diabetic mouse maps to the Idd6 diabetes susceptibility region. Diabetologia 44:1054-1061

Bergman ML, Duarte N, Campino S, Lundholm M, Motta V, Lejon K, Penha-Goncalves C, Holmberg D (2003) Diabetes protection and restoration of thymocyte apoptosis in NOD Idd6 congenic strains. Diabetes 52:1677-1682

Carnaud C, Gombert J, Donnars O, Garchon H, Herbelin A (2001) Protection against diabetes and improved NK/NKT cell performance in NOD.NK1.1 mice congenic at the NK complex. J Immunol 166:2404-2411

Deenick EK, Tangye SG (2007) Autoimmunity: IL-21: a new player in Th17-cell differentiation. Immunol Cell Biol 85:503-505

Duarte N, Lundholm M, Holmberg D (2007) The Idd6.2 diabetes susceptibility region controls defective expression of the Lrmp gene in nonobese diabetic (NOD) mice. Immunogenetics 59:407-416

Frederiksen KS, Lundsgaard D, Freeman JA, Hughes SD, Holm TL, Skrumsager BK, Petri A, Hansen LT, McArthur GA, Davis ID, Skak K (2008) IL-21 induces in vivo immune activation of NK cells and CD8(+) T cells in patients with metastatic melanoma and renal cell carcinoma. Cancer Immunol Immunother 57:1439-1449

Guler ML, Ligons DL, Wang Y, Bianco M, Broman KW, Rose NR (2005) Two autoimmune diabetes loci influencing $\mathrm{T}$ cell apoptosis control susceptibility to experimental autoimmune myocarditis. J Immunol 174:2167-2173

He CX, Avner P, Boitard C, Rogner UC (2010a) Downregulation of the circadian rhythm related gene Arntl2 suppresses diabetes protection in Idd6 NOD.C3H congenic mice. Clin Exp Pharmacol Physiol 37:1154-1158

He CX, Prevot N, Boitard C, Avner P, Rogner UC (2010b) Inhibition of type 1 diabetes by upregulation of the circadian rhythmrelated aryl hydrocarbon receptor nuclear translocator-like 2 . Immunogenetics 62:585-592

Hung MS, Avner P, Rogner UC (2006) Identification of the transcription factor ARNTL2 as a candidate gene for the type 1 diabetes locus Idd6. Hum Mol Genet 15:2732-2742

Kwon H, Jun HS, Yang Y, Mora C, Mariathasan S, Ohashi PS, Flavell RA, Yoon JW (2005) Development of autoreactive diabetogenic $\mathrm{T}$ cells in the thymus of NOD mice. $\mathrm{J}$ Autoimmun 24:11-23

Lebailly B, He C, Rogner UC (2014) Linking the circadian rhythm gene Arntl2 to interleukin 21 expression in type 1 diabetes. Diabetes 63:2148-2157

Leijon K, Hammarstrom B, Holmberg D (1994) Non-obese diabetic (NOD) mice display enhanced immune responses and prolonged survival of lymphoid cells. Int Immunol 6:339-345

McGuire HM, Vogelzang A, Hill N, Flodstrom-Tullberg M, Sprent J, King C (2009) Loss of parity between IL-2 and IL-21 in the NOD Idd3 locus. Proc Natl Acad Sci USA 106:19438-19443

McGuire HM, Walters S, Vogelzang A, Lee CM, Webster KE, Sprent J, Christ D, Grey S, King C (2011) Interleukin-21 is critically required in autoimmune and allogeneic responses to islet tissue in murine models. Diabetes 60:867-875

Mingueneau M, Jiang W, Feuerer M, Mathis D, Benoist C (2012) Thymic negative selection is functional in NOD mice. J Exp Med 209:623-637

Monteleone G, Pallone F, MacDonald TT (2008) Interleukin-21: a critical regulator of the balance between effector and regulatory T-cell responses. Trends Immunol 29:290-294

$\mathrm{Ng}$ PC, Henikoff S (2001) Predicting deleterious amino acid substitutions. Genome Res 11:863-874

Ostiguy V, Allard EL, Marquis M, Leignadier J, Labrecque N (2007) IL-21 promotes $\mathrm{T}$ lymphocyte survival by activating the phosphatidylinositol-3 kinase signaling cascade. J Leukoc Biol 82:645-656

Ozaki K, Spolski R, Ettinger R, Kim HP, Wang G, Qi CF, Hwu P, Shaffer DJ, Akilesh S, Roopenian DC, Morse HC 3rd, Lipsky PE, Leonard WJ (2004) Regulation of B cell differentiation and plasma cell generation by IL-21, a novel inducer of Blimp-1 and Bcl-6. J Immunol 173:5361-5371

Peluso I, Fantini MC, Fina D, Caruso R, Boirivant M, MacDonald TT, Pallone F, Monteleone G (2007) IL-21 counteracts the regulatory $\mathrm{T}$ cell-mediated suppression of human $\mathrm{CD} 4^{+} \mathrm{T}$ lymphocytes. J Immunol 178:732-739

Penha-Goncalves C, Leijon K, Persson L, Holmberg D (1995) Type 1 diabetes and the control of dexamethazone-induced apoptosis in mice maps to the same region on chromosome 6. Genomics 28:398-404

Rafei M, Dumont-Lagace M, Rouette A, Perreault C (2013a) Interleukin-21 accelerates thymic recovery from glucocorticoid-induced atrophy. PLoS One 8:e72801

Rafei M, Rouette A, Brochu S, Vanegas JR, Perreault C (2013b) Differential effects of gammac cytokines on postselection differentiation of CD8 thymocytes. Blood 121:107-117

Rogner UC, Boitard C, Morin J, Melanitou E, Avner P (2001) Three loci on mouse chromosome 6 influence onset and final incidence of type I diabetes in NOD.C $3 \mathrm{H}$ congenic strains. Genomics 74:163-171

Rogner UC, Lepault F, Gagnerault MC, Vallois D, Morin J, Avner P, Boitard C (2006) The Diabetes Type 1 Locus Idd6 Modulates Activity of CD $4{ }^{+} \mathrm{CD} 25^{+}$Regulatory T-Cells. Diabetes 55:186-192

Sim NL, Kumar P, Hu J, Henikoff S, Schneider G, Ng PC (2012) SIFT web server: predicting effects of amino acid substitutions on proteins. Nucleic Acids Res 40:W452-W457

Smink LJ, Helton EM, Healy BC, Cavnor CC, Lam AC, Flamez D, Burren OS, Wang Y, Dolman GE, Burdick DB, Everett VH, Glusman G, Laneri D, Rowen L, Schuilenburg H, Walker NM, Mychaleckyj J, Wicker LS, Eizirik DL, Todd JA, Goodman N (2005) T1DBase, a community web-based resource for type 1 diabetes research. Nucleic Acids Res 33:D544-D549

Sofi MH, Liu Z, Zhu L, Yu Q, Kaplan MH, Chang CH (2010) Regulation of IL-17 expression by the developmental pathway of CD4 T cells in the thymus. Mol Immunol 47:1262-1268

Spolski R, Leonard WJ (2014) Interleukin-21: a double-edged sword with therapeutic potential. Nat Rev Drug Discov 13:379-395

Spolski R, Kashyap M, Robinson C, Yu Z, Leonard WJ (2008) IL-21 signaling is critical for the development of type I diabetes in the NOD mouse. Proc Natl Acad Sci USA 105:14028-14033

Stewart S, Dykxhoorn DMPD, Mizuno H, Yu EY, An DS, Sabatini DM, Chen IS, Hahn WC, Sharp PA, Weinberg RA, Novina CD (2003) Lentivirus-delivered stable gene silencing by RNAi in primary cells. RNA 9:493-501

Sutherland AP, Van Belle T, Wurster AL, Suto A, Michaud M, Zhang D, Grusby MJ, von Herrath M (2009) Interleukin-21 is required for the development of type 1 diabetes in NOD mice. Diabetes 58:1144-1155

Wei L, Laurence A, Elias KM, O'Shea JJ (2007) IL-21 is produced by Th17 cells and drives IL-17 production in a STAT3-dependent manner. J Biol Chem 282:34605-34610

$\mathrm{Xu} \mathrm{H}$, Gustafson CL, Sammons PJ, Khan SK, Parsley NC, Ramanathan C, Lee HW, Liu AC, Partch CL (2015) Cryptochrome 1 regulates the circadian clock through dynamic interactions with the BMAL1 C terminus. Nat Struct Mol Biol 22:476-484

Zeng R, Spolski R, Casas E, Zhu W, Levy DE, Leonard WJ (2007) The molecular basis of IL-21-mediated proliferation. Blood 109:4135-4142 